\title{
Transatlantic Cooperation During the Second World War: The First Stages of Economic Cooperation During the "Phoney War"
}

\author{
Elisabeth du Réau \\ Sorbonne Nouvelle Paris 3, Paris, France
}

\begin{abstract}
During the Second world war, the Franco-British cooperation included the organization of purchasing missions for airnautical material in the States. On 25 november 1939, a Franco-British agreement was set up to organize two purchasing missions in the United States under the control of a "Liaison Committee" supervised by the Treasury Secretary, Henry Morgenthau. Édouard Daladier, French Chief of Government, sent René Pleven to establish contacts with General Arnold (AirCorps). The Franco-British financial contribution facilitated a main spurt in investments which help modernize the American products apparatus. First contacts were established on April 1940, to be delivered in September. While France had not be able to benefit from significant part of these orders, Great Britain would take over some units that were originally allocated to France. These contracts would later facilitate the development of transatlantic cooperation.
\end{abstract}

Keywords: purchasing mission, aeronautical material, planes: bombers and fighters, Liaison Committee, solidarity economy, tripartite negotiation, actors (France, United Kingdom, United States)

Historians have not yet totally clarified the "hidden face" of the "phoney war". These aspects of economic warfare are another dimensions of the struggle against Germany.

In the framework of Franco-British economic cooperation, the creation of the "Franco-British Economic coordination cabinet" (on 20 September 1939) and the choice of Jean Monnet (on 27 September) represent one of the essential axes of Paris's Foreign Policy.

The organization of purchasing missions for aeronautic material in the States was an important challenge.

It often escapes attention that one of Edouard Daladier's first initiatives just after Munich was to organize an impromptu lunch with the American ambassador to Paris, William Bullitt, Jean Monnet, Guy La Chambre and the French President in order to set up an initial purchasing mission for aeronautic material.

Given the clear insufficiency of French aeronautical production that was revealed shortly before Munich, the French government cooperation that had not been approached four years after the start of the First World War.

This coordination presupposed financial agreements that were signed on 13 December 1939. Paul Reynaud and the Chancellor Sir John Simon had managed, after numerous meetings since the end of September, to lay the foundation for real financial cooperation. This accord planned monetary solidarity, the division of war-expenditures and economic solidarity. France was able to negotiate as a partner because Paul Reynaud, the previous autumn, had been able to bring about the return of a great part of exiled capital, which means that one can talk about the reconstitution of a "real war treasury". The two countries undertook to make a fair share or the expenditures in dollars or in gold borne by each and necessitated by the conduct of the war. They were to 
cooperate on price-policy in order to avoid any detrimental disparity and attempt to take out joint-loans. Their purchasing missions in the United States are a good illustration of the positive aspects of this cooperation.

\section{French Initiatives to Establish Contacts With the United States}

\section{The Role of Jean Monnet}

Yet on 8 September 1939 Édouard Daladier received William Bullitt, American ambassador, to approach the President Roosevelt in order to obtain a revision of the Neutrality Act.

In October 1938, after Munich, William Bullitt was invited by Édouard Daladier to establish first contacts between French administration and American Embassy [É du Réau, Édouard Daladier, 1993].

Jean Monnet was selected to conduct this unofficial mission, [William Bullitt, Correspondence with the President Roosevelt].

In September 1939, this role was preeminent. While public opinion was evolving in the United States, various pressures were acted inside American Congress. Jean Monnet worked to bring about tripartite negotiations, between France, Great Britain and United States, [Winston Churchill, Memories, vol.2].

The prospect of the demand offered by the French and British markets would allow for faster profits on the initial investments. The director of the Curtiss Wright Corporation Theodore R. Wright was an expert advisor to the Defense Council played an essential role, [National Archives, Washington].

Many obstacles had to be overcome in order to convince Congress and the Roosevelt administration to modify the Neutrality Act's rules of application.

After lengthy debate, Congress passed a "law of neutrality" that modified the previous clauses, [J Mc Vikar Haight, 1970].

This was an important personal triumph for Roosevelt as well as a victory for Franco-British diplomacy. It was also an important turning point in the history of the cooperation among three democracies.

Indeed the new clauses made it possible to regularize pending contacts and to increase orders future.

\section{A Driving Role for French Government}

It must be noted that French Government and Administration played the driving role in getting these negotiations.

Édouard Daladier hoped to hasten the conclusion of new contacts while Chamberlain was temporizing.

The technical and financial problems that were cropping up worried the French President of the Council. According to the testimony of Bullitt who was asked to lunch on 20 November with the Air Force Minister, Guy La Chambre, Édouard Daladier said : "if it is truly impossible to get the planes that we are requesting from the United States, I had better step down as President of Council.”, [William Bullitt, Correspondence...].

The British Ambassador in Washington, Lord Lothian, was so a good negotiator on November and December 1939 to conclude the contracts.

\section{The Purchasing Mission of Aeronautical Material (on November 1939 to April 1940)}

\section{First Missions}

According to the terms of the Franco-British agreement on 25 November 1939, the Allies United States Purchasing Committee was set up with two Presidents, Bloch-Lainé for France and Purvis for United Kingdom. Under the Committee's Authority two missions French and British were acting in concert.

- Management 
The first missions were managed under the control of a "Liaison Committee" placed under the responsibility of Morgenthau, the American Secretary of the Treasury and assigned to Captain Harry Collins. René Pleven, in charge of French mission, was on 1938, the representing of French government with previous links with Harry Collins.

Bullitt wrote on October 1939: "The airplane situation is approximately the following: the French produced in the month of august 1939, 319 warplanes. The British approximately 450 warplanes. In France, there is another enormous hole in the French defense against the German bombardment planes. The French has practically no modern projectors!" Later, he concluded: "While France and England must produce more planes, the decisive weapon must for obtain by colossal purchases of planes in the United States." [Bullitt Correspondence between Franklin D. Roosevelt and William Bullitt, op.cit.].

In United Kingdom the role of British Commonwealth was expected Royal Canadian Air Force (with fifteen squadrons) and Australia (with six squadrons) were at disposal of the Royal Air Force. [JRM Butler Grand Strategy, ...].

The Dominions even more the United Kingdom suffered a Shortage of equipment. The Anglo-French purchasing Board examined and coordinated Anglo French activities with the supply and purchase of war material including so for France territories of North Africa, [Eric Jennings "Le poids des Empires coloniauxdans la guerre" in AlyaAglan, Robert Frank, la guerre monde, Gallimard, 2015, t 1].

- Technical and financial aspects of purchasing missions

After overriding the inevitable objections on financial grounds from Reynaud in Paris and Chancellor of Exchequer, Sir John Simon, in London, Daladier sent Pleven back to Washington to complete negociations. In the American Army Air Corps, general Arnold attempt to withold the latest aircraft models (capable of matching the new German Messerschmitt models 109s) Morgenthau again appealed to the White House and Roosevelt brought the chief of the army Air Corps to heel. Martin and Douglas bombers were exepted as soon as possible to prevent bombing attacks for German Air Force, [Morgenthau Diaries, vol II...].

\section{First Results Before the Germany Attacks}

Contacts for 2,400 fighters, 2,160 bombers and 13,000 engines were signed on 10 April 1940. These contracts précised than deliveries would begin on September 1940! Experts were expected to precise reception and assembling process. First deliveries would be arrive in North Africa. This process would be examined under the control of general Nogues [Levisse-Touzé Christine, L'Afrique du Nord...,].

Of the 555 American combat aircraft that the French Government had purchased in the spring of 1938 and January 1939, only Curtiss P 36 Haw fighters had been delivered. After the repeal of the American Arms embargo on 3 November 1939, convoys carrying Martin and Douglas attack bombers would arrive in Morocco to be assembled.

When the German offensive began on 10 May 1940, the French Air Force had received only 137 fully assembled aircraft for use against invaders [Haight, American Aid to France, op. cit.].

Must one conclude that the Allied missions to the United States were in failure!

While France had not been able benefit from a noteworthy part of the orders, Great Britain would take over a significant number of units that where initially meant for France.

The Franco British financial contributions facilitated a significant spurt in investments which helped 
modernize the American products apparatus.

The contacts, that had been established, would later facilitate the development of a collaboration of a totally different scope. Yet the foundations of transatlantic cooperation had been laid down in 1938-1940. We concluded with the testimony of the American Ambassador in Paris, William Bullit "I urged the President Roosevelt to increase the production of airplanes, both in order to supply France and England and in case of their defeat to have the United States in a formidable position to oppose any German threat", [Bullitt, ...For the President..., op.cit.].

This commentary confirms the role of this these Allied missions in the framework of transatlantic cooperation.

\section{References}

Bullitt, O. H. (Ed.). (1972). For the President, personal and secret, Correspondence between Franklin D. Roosevelt and William Bullitt, Houghton Mifflin Company, Boston.

Butler, J. R. M. (1957). Grand strategy, $t$ II. London: HM Stationery Office.

Churchill, W. (1948). The Second world war, the Gathering Storm, t1. London.

Frank, R. (1982). Le prix du réarmement français (1935-1939). Paris, Publications de la Sorbonne.

Frank, R., \& Aglan, A. (2015). La guerre mondiale, t1. Paris, Gallimard.

MacVictor, H. J. (1970). American Aid to France, 1938-1940. New York: Atheneum.

Christine, L.-T. (1991). L'Afrique du Nord: Recours ou secours septembre 1939-juin 1943. Paris, Paris 1 Panthéon Sorbonne, Thèse d'État (s/dir. Guy Pédroncini).

Jean, M. (1976). Memoires. Paris:Fayard.

John, M. B. (1965). From the Morgenthau diaries: Years of urgency 1938-1941. Boston: Houghton Mifflin.

Réau Élisabeth du. (2007). L'ordre mondial: De Versailles à San Francisco juin 1919-juin 1945. Paris: Puf.

Réau Élisabeth du. (1993). Édouard Daladier. Paris: Fayard.

Reynaud Paul. (1951). Au Cour de la mêlée. Paris: Flammarion.

Werth Alexander. (1982). The twilight of France 1933-1940. London: H. Macmillan. 